\title{
Meslek Hastalığı olarak Brusella Saptanan ve Kas-İskelet Sistemi Bulguları olan Aynı Köyde Yaşayan İki Olgu
}

\author{
Two Cases Living in the Same Village Who have Musculoskeletal System Symptoms and are \\ Diagnosed with Brucellosis as Industrial Illness
}

\author{
Safinaz ATAOĞLU*, Merve DEDE
}

Düzce Üniversitesi Tip Fakültesi Fiziksel Tıp ve Rehabilitasyon AD, Düzce

\begin{abstract}
ÖZ
Bruselloz, özellikle Akdeniz ve Orta Asya ülkeleri başta olmak üzere tüm dünya üzerinde yaygın şekilde dağılım gösteren sistemik ve enfeksiyöz bir hastalıktır. Bruselloz; ateş, gece terlemeleri, iştahsızlık, kilo kaybı, halsizlik, şiddetli baş ağrısı ve poliartralji gibi nonspesifik semptomlarla başlar. Bulguların ortaya çıkması hastalık süresi ile ilişkilidir. Brusellozun tuttuğu sistemlerden biri de kas iskelet sistemidir. Kas iskelet sisteminde; periferik artrit, sakroileit, spondilit, tenosinovit, bursit ve osteomyelit görülür. Bu olgu sunumunda yaygın eklem ağrısı, bel ağrısı, dirsekte ağrı ve şişlik ile gelen ve aynı köyde oturan iki erkek hastada meslek hastalığı olarak saptanan brucella spondiliti, olekranon bursiti ve artriti sunuldu.

Anahtar kelimeler: Bruselloz; brusella artriti; artralji; spondilit; olekranon bursiti.

\section{ABSTRACT}

Brucellosis is a systemic and infectious disease which spreads all around the world but mostly Mediterranean and Middle Asian countries. Brucellosis begins with non-specific symptoms such as fewer, night sweating, anorexia, weight loss, weakness, severe headache and polialtralgia. Appearance of symptoms is connected with duration of disease. One of the systems which brucellosis holds onto is the musculoskeletal system. Peripheral arthritis, sacroiliitis, spondylitis, tenosynovitis, bursitis and osteomyelitis can be seen on musculoskeletal system. In two case, brucellosis spondylitis, olecranon bursitis and arthritis which is detected as industrial illness on two men living in the same village, having arthralgia, backache, elbow pain and swelling is reported.

Keywords: Brucellosis; brucellosis arthritis; arthralgia; spondylitis; olecranon bursitis.
\end{abstract}

\section{GİRIŞ}

Brusella bakterileri küçük, gram negatif kokobasillerdir. Hayvanlarda düşük ve infertilite yaparak kronik enfeksiyona neden olur. Ülkemizde daha çok brusella melitensis (koyun, keçi) ve brusella abortus (sığır) ile hastalık oluşmaktadır. Meslek hastalığı olarak enfekte hayvanlardan insana doğrudan veya sıklıkla çiğ süt ve süt ürünleri ile bulaşmaktadır $(1,2)$. Süt ve süt ürünleri kaynatılarak veya pastörize edilerek bakteri inaktive olur. Her yaşta görülebilir ve her iki cinsi eşit olarak tutar. Brusella bakterileri vücuda girdikten sonra hematojen yolla yayılarak sistemik hastalık oluşturur. Ateş, terleme, iştahsızlık, kırıklık, bel ağrısı gibi nonspesifik belirtilerle başlar daha sonra sistemik belirtiler ortaya çıkar. Tedavi edilmeyen hastalarda ondülan ateş ile özellikle akşamları ortaya çıkan bol ve kötü kokulu terleme tipiktir. Semptomlar bir yıldan uzun sürerse kronik bruselloz olarak değerlendirilir. Bu durumda kemik, karaciğer, dalak gibi organlarda süpüratif lezyonlar oluşur.

Brusellanın tuttuğu sistemlerden biri olan kas iskelet sistemi brusellozun en sık (\%40) tutulan sistemlerinden biridir (3). Kas iskelet sisteminde; periferik artrit, sakroileit, spondilit, tenosinovit, bursit, osteomyelit yapar (4). Brusellozun en s1k görülen kas iskelet sistem bulgusu sakroileittir sonra sırasıyla periferik artrit-artralji, spondilit, osteomyelit ve bursit görülür (5). Sakroileit genellikle unilateraldir, destrüksiyon yapmaz, antibiyotik tedavisine cevap verir.

Artrit sıklıkla monoartrit veya asimetrik periferik oligoartrit şeklindedir. Artrit enfeksiyoz veya reaktif artrit şeklindedir. Enfeksiyon süresi uzadıkça artrit gelişme sıklığı artar. Genelde artritin başlangıcı akut ve çok ağrılıdır, etkilenen eklemde kızarıklık, 1Sı artış1, efüzyon ve hareket kısıtlılığı oluşur (6). Periferik brusella artriti genellikle büyük ve ağırlık taşıyan kalça, diz, ayak bileği eklemlerini tutar. Nadiren sternoklavikular eklem gibi diğer eklemler de tutulabilir (7). Periferik artrit antibiyotik tedavisine cevap verir ancak spontan nüksler görülebilir. Spontan nüksler genellikle brusella reaktif artrititir. 
Brusella spondiliti lokal bel ağrısı yapar. Ateş, baş ağrısı, splenomegali, güçsüzlük ve anemi ile beraber görülebilir. En çok lomber vertebraları tutar ve birkaç vertebra birden tutulur. Başlangıçtaki ağrı gittikçe artar ve çok şiddetlidir ancak yatınca azalır, paravertebral kas spazmı çok fazladır. İleri yaşlarda ve kronik seyirli enfeksiyonlarda daha sık görülür. Osteomyelit, septik diskit, vertebra korpusu epifizitine bağlı vertebranın üst ön köşesinde erozyon oluşur. Bu durum disk harabiyetine, eklem aras1 mesafenin daralmasina, osteofit, sindesmofit ve paravertebral abse oluşumuna neden olabilir Paravertebral abseler antibiyotik direncine neden olur, abse direne edilmedikçe tedavi mümkün olmaz.

$\mathrm{Bu}$ olguda; klinik şüphenin tanı gecikmelerinin önüne geçebileceği düşünülerek, nonspesifik semptomlar nedeni ile tanı koymada zorluk çekilen, bölgemizde çok nadir görülen brusellozu olan ve eklem ağrıları ile başvuran aynı köyde yaşayan iki hasta tartışıldı.

\section{OLGU SUNUMU}

Birinci olgu; 52 yaşında erkek hasta, polikliniğimize yaklaşık 7 aydır devam eden eklem ağrıları, her iki dirsekte ağrı, şişlik şikayetiyle başvurdu. Eklem ağrılarına ataklar halinde gelen ateş, gece terlemeleri ve genel durum bozukluğu eşlik ediyormuş. Ağrılar belirgin olarak her iki dirsek, her iki diz ve sol kalçadaymış. İki ay önce sol testiste şişlik, 1s1 artışı ve ağrı şikayetiyle üroloji polikliniğine başvurmuş, siprofloksasin $1000 \mathrm{mg} /$ gün kullanımı sonrası şikayetleri geçmiş. Hastanın mesleği sığır ve koyun çobanlığı olup, hayvan doğumlarına

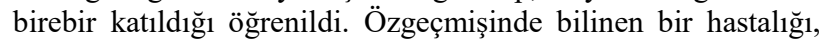
ilaç kullanım öyküsü yoktu, soy geçmişi özellik arz etmiyordu. Lokomotor sistem muayenesinde; her iki diz ekleminde şişlik, 1s1 artışı, eklem hareket kısıtlı1ı̆̆ 1 vardı. Sol FABERE testi pozitifti. Her iki dirsek ekleminde olekranon bursiti saptandı (Resim 1a,b, 2).
Laboratuvar bulguları; sedimantasyon $89 \mathrm{~mm} / \mathrm{saat}$, CRP 13,9 (0$0,5)$, RF negatif, biyokimya, hemogram, periferik yayma sonuçları normaldi. Rose Bengal tarama testi pozitif gelmesi üzerine brusella tüp aglutinasyon testi istendi. Brusella tüp aglütinasyonu 1/160 titrede üç pozitif saptand. Eklem grafileri normaldi. Diz ve kalça manyetik rezonans görüntülemesinde (MRG) eklemde sıvı artışı vardı. Hastaya bruselloz tedavisi olarak doksisiklin $200 \mathrm{mg} /$ gün akşamları, rifampin $600 \mathrm{mg} / \mathrm{gün}$ sabah altı hafta boyunca verildi. Dize soğuk tedavi uyguland, bursit boşaltılmadı. Hastanın bilateral diz artriti, kalça artraljisi ve olekranon bursiti tedavi sonrası düzeldi.

İkinci olgu; ilk olgudan 15 gün sonra polikliniğimize 6 aydır devam eden bel ağrısı ile başvurdu. Elli yaşında erkek hasta bel ağrısının devamlı olduğunu, gece gündüz, hareketle istirahatle azalmadığını kalçalarına ve bacaklara vurmadığını söyledi. Bel ağrısı yanında ataklar halinde gelen ateş, gece terlemeleri oluyormuş. Hasta sığır ve koyun yetiştiriciliği yapıyormuş, birinci olgu bu hastanın yanında çalışıyormuş. Özgeçmişinde diabetes mellitusu (DM) olan hastanın bilinen başka bir hastalığı, DM ilaçları dışında ilaç kullanım öyküsü yoktu, soygeçmişi özellik arz etmiyordu. Lokomotor sistem muayenesinde; lomber kolon hareketleri her yöne ağrılı ve kısitlıydı. İki taraflı paravertebral kas spazmı vard1. Lomber Schober testi $(11 \mathrm{~cm})$ pozitifti. Laboratuvar bulgular1; sedimantasyon $47 \mathrm{~mm} / \mathrm{saat}$, CRP $2.12(0-0,5)$, RF negatif, biyokimya, hemogram, periferik yayma sonuçları normaldi. Rose Bengal tarama testi pozitif gelmesi üzerine brusella tüp aglutinasyon testi istendi. Brusella tüp aglütiasyonu 1/160 titrede iki pozitif saptand. Lomber MRG'de; L4-L5 vertebra korpuslarında T1AG hipointens, T2AG'de heterojen intensitede sinyal değişiklikleri olup spondilit saptand (Resim 3a,b,c). Hastaya bruselloz tedavisi olarak doksisiklin 200 $\mathrm{mg} /$ gün akşamları, rifampin $600 \mathrm{mg} /$ gün sabah altı hafta boyunca verildi. Hasta bu tedavi sonrası düzeldi.

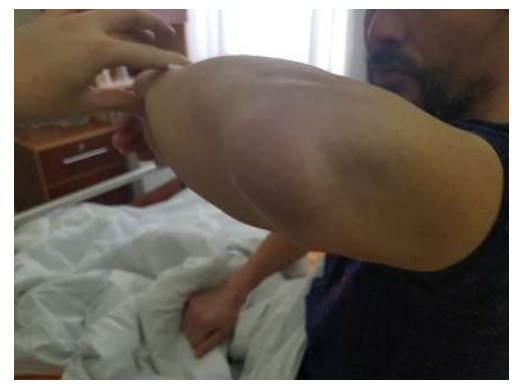

Resim 1a,b. Sağ olekranon bursiti
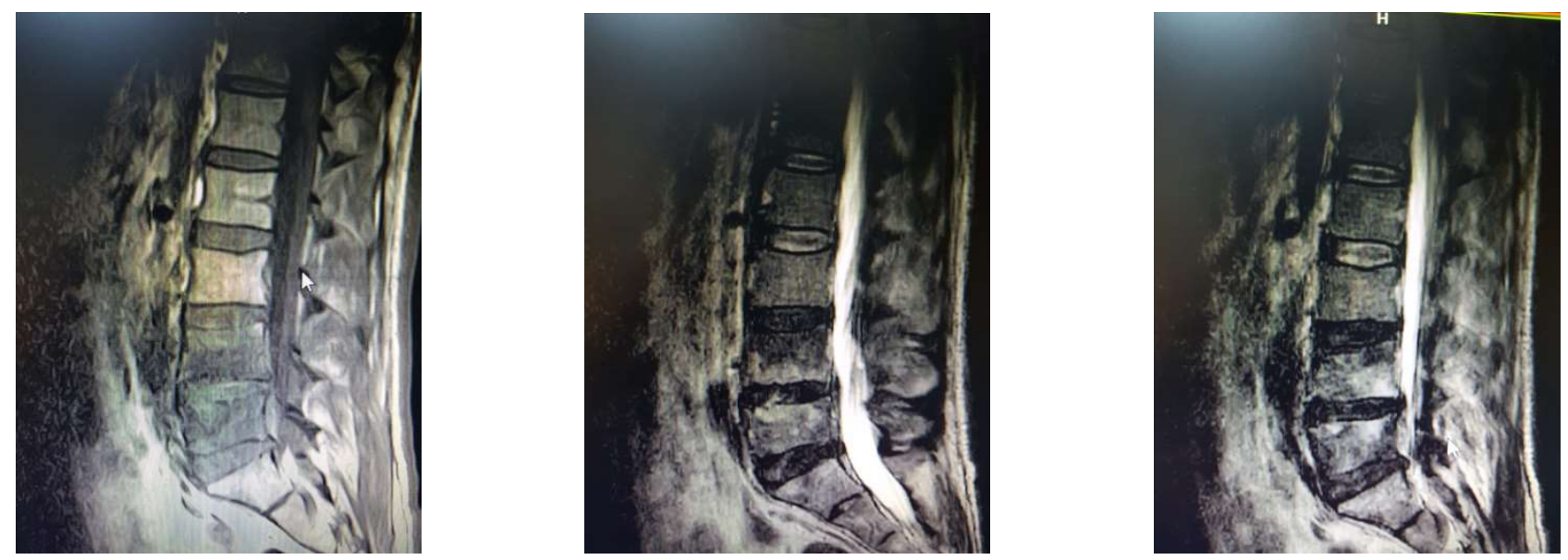

Resim 3. Lomber MRG'de L4-5 vertebra korpuslarında (a) T1AG'de hipointens (b,c) T2AG'de heterojen intensite değişiklikleri içeren spondilit

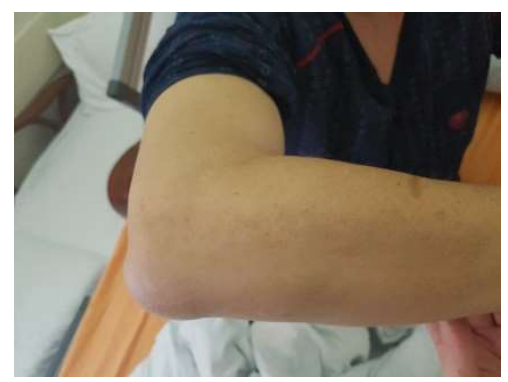

Resim 2. Sol olekranon bursiti 


\section{TARTIŞMA}

Bruselloz dünyada ve ülkemizde yaygın görülen bir hastalıktır $(1,2)$. Ülkemizde bruselloz epidemiyolojisi ile ilgili yapılan çalışmalarda seropozitifliğin \%1.8-6, morbidite hızının 20.3/100,000 olduğu gösterilmiştir $(8,9)$. Brusellozda semptomlar nonspesifik olduğu için tanının konabilmesi için klinik tablonun iyi bilinmesi önemlidir. Bizim iki olgumuzda nonspesifik semptomlarla başladığı için tanı konamamış 6-7 aylık gecikmelerle bize başvurmuştur. Bölgemizde süt ve süt ürünleri pişirilerek kullanıldığ 1 için diğer bölgelere göre nadirdir. Bu nedenlerle de tanı atlanabilmektedir.

Enfekte hayvanlarla veya hayvan ürünleriyle meslek gereği cilt, solunum, mukoza, konjuktiva ile temasın olması bruselloz için risk etmenidir (10). Bruselloz şüphesi olan bir hastada meslek öyküsü, yaşam alanı, beslenme alışkanlıklarının sorgulanması gerekir. Bizim iki olgumuz hayvancılıkla uğraştığı için meslek hastalığı olarak bruselloz oluşmuştur.

Kuluçka süresi ortalama 1-3 hafta kadardır. Bu dönem zarfında hastaların \%15-50'sinde kemik iliği veya kan kültüründe bakterinin üretilmesi ile tanı konabilir. Bakteriyolojik kanıtın yokluğunda brusella için serolojik tanıda; antikor titresinin 1/160'dan yüksek olması, standart tüp aglütinasyon testiyle antikor titresinde 4 kat kadar artışı veya ELISA (Enzyme-Linked Immunosorbent Assay) yöntemiyle titrasyonda yükselme olması tanı için değerlidir. Ateşli dönemde antikor titresi düşük olduğundan aglütinasyon testinin tanıda değeri önemlidir $(11,12)$. Bizim olgularımızda da antikor titreleri tanıyı destekliyordu.

Brusellozda klinik bulgular arasında ateşli ve osteoartiküler bulguların (sırt ağrısı, artrit, artralji, miyalji) ön planda olduğu bildirilmiştir. Ülkemizde yapılan çalışmalarda en sık görülen semptom ateştir ve bunu artrit/artralji izlemektedir $(13,14)$. Yurt dışında yapılan çalışmalarda ise eklem semptomlarının daha sık görüldüğü bildirilmiştir $(15,16)$. Bu sonuçlar, sadece eklem yakınmaları ile başvuran hastaların tanıları arasında brusellozun da düşünülmesinin önemini ortaya koymaktadır. Eklem ağrısına eşlik eden semptomlar bu noktada kilit rol oynamaktadır. Semptomların derinlemesine sorgulanması yol gösterici olacaktır. Olgumuzda ateş sorgulandığında ateşin akşama doğru yavaş bir şekilde yükseldiği, en yüksek seviyeye çıktıktan sonra yavaş düşme gösterdiği ve 4-5 gün ateşsiz dönemlerden sonra tekrar yükseldiği öğrenildi. Düşme ve yükselmelerle giden ondülan tarzda ateş bruselloz akla gelmelidir. Olgumuzda olduğu gibi eklem ağrısına ateş ve gece terlemelerinin eşlik ettiği durumlarda veya sadece eklem ağrıları olan hastalarda mutlaka bruselloz ayırıcı tanıda düşünülmelidir.

Brusellozda serolojinin başlangıçta negatif olması da yanıltıcı olmaktadır. Bu aşamada öykü ve fizik muayene çok önemlidir. Brusella tüp agglütinasyon testinin kontrolü sonuçlanana kadar tedavi ile hastanın şikayetlerinin gerilemeye başlaması da bu durumu destekler. Kas iskelet sistemi tutulumu olan bruselloz hastalarının progresyonu genellikle iyidir. Medikal tedavi olarak; doksisiklin $200 \mathrm{mg} /$ gün ve rifampin $600 \mathrm{mg} / \mathrm{gün}$ kombinasyonuyla hastaların çoğunda artiküler ve sistemik bulgular 6 hafta içerisinde azalır (12). Yapılan çalışmalarda bruselloz tedavisinde erken tanının çok önemli olduğu ve hızlı bir şekilde tedaviye başlamanın yüz güldürücü sonuçlar verdiği vurgulanmıştır (17).

Sonuç olarak artralji, ateş, halsizlik kırgınlık gibi nonspesifik semptomları olan hastalarda brusellanın ayırıcı tanıda önemli bir yer tuttuğu akılda bulundurulmalıdır. Serolojik testlerin negatif olabildiği durumlarda öykü ve fizik muayenenin erken tanı için yol gösterici olduğu hatırlanmalıdır.

\section{KAYNAKLAR}

1. Yalçın I. Bruselloz. Neyzi O, Ertuğrul T, editörler. Pediatri. 3. Bask1. İstanbul: Nobel Kitabevleri; 2002.

2. Young EJ. Brucellosis. In: Feigin RD, Cherry JD, Demmler GJ, Kaplan SL, editors. Textbook of pediatric infectious diseases. 5th ed. Philadelphia: Saunders; 2004. p.1852-88.
3. Öncel S. Brusella enfeksiyonları: değerlendirme ve yönetim. KOU Sag Bil Derg. 2016;2(3):25-30.

4. Tali ET. Spinal infections. Eur J Radiol. 2004; 50(2):120-33.

5. Ibero I, Vela P, Pascual E. Arthritis of shoulder and spinal cord compression due to Brucella disc infection. $\mathrm{Br} \mathrm{J}$ Rheumatol. 1997;36(3):377-81.

6. Alkan BM, Çalap B. Brusella'da kas-iskelet sistemi bulguları. Fiziksel Tip. 2004;7(2):99-104.

7. Berrocal A, Gotuzzo E, Calvo A, Carrillo C, Castañeda O, Alarcón GS. Sternoclavicular brucellar arthritis: A report of 7 cases and a review of the literature. J Rheumatol. 1993;20(7):1184-6.

8. Çetin ET, Çoral B, Bilgiç A, Bilgehan H, Sipahioğlu U, Gürel $\mathrm{M}$, ve ark. Türkiye'de insanda bruselloz insidansının saptanmas1. Doğa Turk J Med Sci. 1990;14:324-34.

9. Palanduz A, Telhan L, Kadıoğlu E, Erdem E, Öztürk AO. Çocukluk çağında bruselloz: 43 olgunun değerlendirilmesi. Çocuk Enf Derg. 2007;1(4):139-42.

10. Yagupsky P. Pediatric brucellosis: An (almost) forgetten disease. Adv Exp Med Biol. 2011;719:123-32.

11. Aydin G, Tosun A, Keles I, Ayaşlioglu E, Tosun O, Orkun S. Brucellar spondylodiscitis: A case report. Int J Clin Pract. 2006;60(11):1502-5.

12. Lauie JS, Bocanegra TS. Osteoarticular brucellosis. In: Hochberg MC, Silman AJ, Smolen JS, Weinblatt ME, Weisman MH, editors. Rheumatology. 3th ed. Edinburgh: Mosby; 2003. p.1081-2.

13. Vardar F, Gökşen D, Özkınay C, Kurugöl Z, Özkınay F. Bruselloz tanı ve sağaltımı. Ege Pediatri Bülteni. 2000;7(1):29-32.

14. Yılmaz E, Kabakuş N, Akarsu S, Yaşar F, Doğan Y. Çocuklarda brusellozis: 35 olgunun değerlendirilmesi. İç Hastalıkları Dergisi. 1999;6(6):291-4.

15. Mantur BG, Akki AS, Manalgi SS, Patil SV, Gobbur RH, Peerapur BV. Childhood brucellosis-a microbiological, epidemiological and clinical study. J Trop Pediatr. 2004;50(3):153-7.

16. Khuri-Bulas NA, Daud AH, Azb SM. Treatment of childhod brucellosis: Result of a prospective trial on 113 children. Pediatr Infect Dis J. 1993;12(5):377-81.

17. Turgut M, Sendur OF, Gurel M. Brucellar spondylodiscitis in the lumbar region. Neurol Med Chir (Tokyo). 2003;43(4):210-2. 